\title{
Surface energetics to assess biomass attachment onto hydrophobic interaction adsorbents in expanded beds
}

\author{
Rami Reddy Vennapusa ${ }^{\mathrm{a}}$, Canan Tari ${ }^{\mathrm{b}}$, Rosa Cabrera ${ }^{\mathrm{a}}$, Marcelo Fernandez-Lahore ${ }^{\mathrm{a}, *}$ \\ a Downstream Processing Laboratory, Jacobs University gGmbH, Campus Ring 1, D-28759 Bremen, Germany \\ ${ }^{\mathrm{b}}$ Department of Food Engineering, Izmir Institute of Technology, Urla, Izmir 35430, Turkey
}

\section{A R T I C L E I N F O}

\section{Article history:}

Received 30 June 2008

Received in revised form 31 July 2008

Accepted 1 August 2008

\section{Keywords:}

Direct sequestration

Biomass attachment

Fluidized beds

Sorption performance

Surface energetics

Bioprocess design

Hydrophobic interaction

\begin{abstract}
A B S T R A C T
Cell-to-support interaction and cell-to-cell aggregation phenomena have been studied in a model system composed of intact yeast cells and Phenyl-Streamline adsorbents. Biomass components and beaded adsorbents were characterized by contact angle determinations with three diagnostic liquids and zeta potential measurements. Subsequently, free energy of interaction vs. distance profiles between interacting surfaces was calculated in the aqueous media provided by operating mobile phases. The effect of $\mathrm{pH}$ and ammonium sulphate concentration within the normal operating ranges was evaluated. Calculation indicated that moderate interaction between cell particles and adsorbent beads can develop in the presence of salt. Cell-to-cell aggregation was suspected to occur at high salt concentration and neutral pH. Predictions based on the application of the XDLVO approach were confirmed by independent experimental methods like biomass deposition experiments and laser diffraction spectroscopy. Understanding biomass attachment onto hydrophobic supports can help in alleviating process limitations normally encountered during expanded bed adsorption of bioproducts.
\end{abstract}

(C) 2008 Elsevier B.V. All rights reserved.

\section{Introduction}

Expanded bed adsorption (EBA) has been proposed as an integrative downstream processing technology allowing the direct capture of targeted species from an unclarified feedstock, e.g. a cell containing fermentation broth. The application of EBA implies, however, that intact cell particles or cell debris present in the feedstock will interact - in a minor or larger extent - with fluidized adsorbent beads. It is already known that interaction between biomass and the adsorbent phase may lead to the development of poor system hydrodynamics and therefore, impaired sorption performance [1,2].

Previous studies on biomass-adsorbent interactions were restricted to simple diagnostic tests to determine the extent of cell - or cell debris - attachment to the desired chromatographic supports [3]. More recently, a single property of the suspended biological particle, i.e. the zeta potential has been proposed for a better understanding and prediction of biomass-adsorbent interactions during expanded bed adsorption. Since then a number of studies have been developed to illustrate the usefulness of this approach

\footnotetext{
* Corresponding author. Tel.: +494213646.

E-mail address: m.fernandez-lahore@jacobs-university.de (M. Fernandez-Lahore).
}

when adsorption is performed onto anion-exchangers [4,5]. Such systems are obviously dominated by Coulomb-type interactions and therefore, non-electrostatic interactions are anticipated to play a minor role [6].

Experimental evidence gathered by many authors has addressed the importance of non-electrostatic forces for biomass adhesion to process surfaces in the broader context provided by a group of systems of technical and environmental relevance. For example, hydrophobic interaction as measured by partition tests has been proposed as a generalized assay to measure adhesion-potential of bacteria to low-energy surfaces [7]. Complementarily, differences in the hydrophobic surface characteristics of bacterial strains were revealed by hydrophobic interaction chromatography [8]. Recently, acid-base interactions have been employed to understand yeast deposition onto chemically modified substrates [9]. However, very little is known on biomass attachment onto chromatographic materials like hydrophobic interaction media (HIC) under real downstream process conditions. The mentioned chromatographic mode represents a widely utilized industrial operation [10], which is amenable for direct sequestration of bioproducts. Since sorption performance limitations were already observed due to biomass interference during HIC-based EBA, a better understanding and control of such phenomena is needed [11].

A more comprehensive approach to understand biomass deposition onto chromatographic supports has been proposed by utilizing 


\begin{tabular}{|c|c|}
\hline \multicolumn{2}{|c|}{ Nomenclature } \\
\hline$A$ & Hamaker constant $(k \mathrm{~T})$ \\
\hline $\mathrm{AB}$ & acid-base \\
\hline DLVO & $\begin{array}{l}\text { classical DLVO theory (Derjaguin, Landau, Verwey } \\
\text { and Overbeek) }\end{array}$ \\
\hline EBA & expanded bed adsorption \\
\hline EL & electrostatic \\
\hline$\Delta G$ & interfacial free energy at $1.57 \AA ̊$ approach $\left(\mathrm{mJ} \mathrm{m}^{-2}\right)$ \\
\hline$\overline{h_{0}}$ & closest distance of approximation $(1.57 \AA)$ \\
\hline$H$ & $\begin{array}{l}\text { distance between surfaces, measured from outer } \\
\text { edge }(\mathrm{m})\end{array}$ \\
\hline HIC & hydrophobic interaction chromatography \\
\hline IC & intact yeast cell particles \\
\hline$k$ & Boltzmann constant $\left(\mathrm{J} \mathrm{K}^{-1}\right)$ \\
\hline LW & Lifshitz-Van der Waals \\
\hline$R$ & radius of the particle $(\mathrm{m})$ \\
\hline$T$ & absolute temperature $(\mathrm{K})$ \\
\hline$U$ & interfacial energy of interaction $(k \mathrm{~T})$ \\
\hline XDLVO & extended DLVO theory, according to Van Oss \\
\hline \multicolumn{2}{|c|}{ Greek letters } \\
\hline$\alpha$ & lumped biomass attachment coefficient \\
\hline$\varepsilon$ & dielectric constant of the medium \\
\hline$\gamma^{\mathrm{AB}}$ & $\begin{array}{l}\text { polar or acid-base component of surface tension } \\
\left(\mathrm{mJ} \mathrm{m}^{-2}\right)\end{array}$ \\
\hline$\gamma^{\mathrm{LW}}$ & $\begin{array}{l}\text { apolar or Lifshitz-Van der Waals component of sur- } \\
\text { face tension }\left(\mathrm{mJ} \mathrm{m}^{-2}\right)\end{array}$ \\
\hline$\gamma^{-}$ & $\begin{array}{l}\text { electron-donor component of surface tension } \\
\text { (Lewis base) }\left(\mathrm{mJ} \mathrm{m}^{-2}\right)\end{array}$ \\
\hline$\gamma^{+}$ & $\begin{array}{l}\text { electron-acceptor component of surface tension } \\
\text { (Lewis acid) }\left(\mathrm{mJ} \mathrm{m}^{-2}\right)\end{array}$ \\
\hline$\kappa$ & inverse of Debye length (m) \\
\hline$\zeta$ & zeta potential (mV) \\
\hline
\end{tabular}

principles of colloid theory to explain biomass-adsorbent attachment at the local (particle) level [12]. This approach is based on extended DLVO calculations performed via experimentally determination of contact angles and $z$-potential values for the interacting surfaces or particles. The comprehensive method takes into account several types of possible interaction forces, i.e. Lifshitz-Van der Waals (LW) and acid-base (AB) and, therefore, it is not limited to those purely electrostatic in nature (EL). Biomass adhesion behavior onto chromatographic beads predicted on the basis of XDLVO calculations was validated by independent biomass deposition experiments [13].

The aim of this paper was to contribute to a deeper understanding of biomass-adsorbent interactions to further open the pave for optimized EBA processing in industry. Studies targeted biomass adhesion to hydrophobic interaction materials which have not been extensively studied so far. The physicochemical properties of biomass-derived material, taken as colloidal particles, vs. the physicochemical properties of the adsorbent beads, taken as a process surface, were determined indirectly via contact angle and zeta-potential measurements. Subsequently, total interfacial interaction energy values were calculated as a function of surface distance in aqueous media, e.g. process buffer. Cell-to-support interactions and cell-to-cell aggregation phenomena were independently confirmed by colloid deposition experiments and laser diffraction spectroscopy, respectively.

\section{Materials and methods}

\subsection{Materials}

Chromatographic matrices (Phenyl Sepharose FF, high substitution; Phenyl Streamline) and columns (Tricorn 5/50) were purchased from GE Health Care (Munich, Germany). $\alpha$-Bromonaphtalene and formamide were obtained from Fluka (Buchs, Switzerland). Water was Milli-Q quality. All other chemicals were analytical grade.

\subsection{Generation of biomass}

Yeast cells (Saccharomyces cerevisiae) wild strain was utilized. Five $\mathrm{ml}$ of $24 \mathrm{~h}$ culture were inoculated in $500 \mathrm{ml}$ of $3.5 \%(\mathrm{w} / \mathrm{v})$ YES medium (yeast extract with supplements of yeast extract, $5 \mathrm{gl}^{-1}$; glucose, $30 \mathrm{gl}^{-1} ; 225 \mathrm{mg} \mathrm{l}^{-1}$ adenine, histidine, leucine, uracail and lysine hydrochloride) and grown at $30^{\circ} \mathrm{C}$. Cells are harvested at late exponential phase by centrifugation, and washed three times with $10 \mathrm{mM}$ phosphate buffer solutions, as previously described [14]. Cells were employed immediately after preparation for further experimental measurements or routines.

\subsection{Physicochemical characterization of cells and beads}

\subsubsection{Contact angle measurements}

Preparation of intact yeast cells for contact angle measurements was performed as described [15]. To evaluate the effect of $\mathrm{pH}$, washed cells were suspended to $10 \%(\mathrm{w} / \mathrm{v})$ in $20 \mathrm{mM}$ phosphate buffer, $\mathrm{pH} 7$ or $50 \mathrm{mM}$ sodium acetate buffer, $\mathrm{pH} 4$ and to evaluate the effect of salt concentration, biomass was suspended in $20 \mathrm{mM}$ phosphate buffer ( $\mathrm{pH} 7$ ) and $50 \mathrm{mM}$ sodium acetate buffer $(\mathrm{pH} 4)$ containing added ammonium sulphate $(0.2,0.4,0.8,1.2,1.6$ and $2.0 \mathrm{M})$. Cells were equilibrated in the appropriate buffer condition and the suspension subsequently poured onto agar plates containing $10 \%$ glycerol and $2 \%$ agar-agar. The plate was allowed to dry for 24-36 h at room temperature on a properly leveled surface free from dust. Salt crystallization was avoided. Agar plates without cell spreads were utilized as control.

Contact angles were measured as per the sessile drop method [16] utilizing a commercial goniometric system (OCA 20, Data Physics instruments $\mathrm{GmbH}$, Filderstadt, Germany). The three diagnostic liquids $\alpha$-bromonaphtalene, formamide, and water were employed [17]. All the measurements were performed in triplicate and at least 20 contact angles per samples were measured.

Contact angle determination on buffer-equilibrated chromatographic beads was performed utilizing the same physicochemical conditions and experimental procedures described for cell particles. Previous to pouring onto the agar plates, matrix beads were frozen in liquid nitrogen and crushed mechanically. Crushing efficiency was assessed by microscopic examination and particle size determination so as to assure particle fragment diameters $\leq 10 \mu \mathrm{m}$. Phenyl Sepharose (high-sub) was utilized. Square pieces of the agar supported chromatographic bead fragments were utilized for measuring contact angles.

\subsubsection{Zeta-potential determination}

Zeta-potential measurements were performed with a ZetaSizer Nano-ZS (Malvern instruments, Worcestershire, United Kingdom), as previously described [12]. Zeta-potential values were gathered employing biomass pretreated as described before (under Section 2.3.1) and utilizing the same buffers utilized for contact angle determination.

Zeta-potential values for crushed and equilibrated chromatographic beads were calculated from the electrophoretic mobility 
data according the Smoluchowski's equation [18]. Data was gathered under identical buffer compositions as shown for biomass related determinations.

\subsubsection{Particle size determination and cell aggregation behavior}

Particle size determinations and cell aggregation studies were performed by laser diffraction employing a MasterSizer 2000, hydro $2000 \mathrm{G}$ (Malvern instruments, Worcestershire, United Kingdom), according to manufacturer instructions. Cell aggregation was studied as a function of $\mathrm{pH}$ and ammonium sulphate concentration utilizing the buffers systems already described. For each condition, kinetic studies were performed within a time interval of $60 \mathrm{~min}$ [19]. Measurements were performed utilizing cell suspensions having an optical density $\approx 0.1$ for better reproducibility.

Visual inspection of aggregate formation was performed with a confocal laser scanning microscope, equipped with argon and helium/neon mixed gas laser with excitation wavelengths of 488 or 543 nm (LSM 510, Carl Zeiss, Oberkochen, Germany). Washed yeast cells in $20 \mathrm{mM}$ phosphate buffer ( $\mathrm{pH} 7$ ) or buffered $1.6 \mathrm{M}$ ammonium sulphate solution were mounted on glass slides and observed. Scans at a resolution of $1024 \times 1024$ pixels were taken in the lineaveraging mode. Micrographs were stored in LSM format (Carl Zeiss LSM Image Browser).

\subsection{Bio-colloid deposition experiments}

Biomass deposition experiments were performed automatically employing an ÄKTA Explorer 100 system (GE Health Care, Munich, Germany) as previously described [13]. These experiments were run by introducing a population of yeast cells particles is introduced into a system composed of collector (adsorbent) beads; the suspended biomass effluent is monitored as a function of process time. This type of experiments can provide useful and quantitative information when assessing factors like cell size and shape, microorganisms strain, growth phase, bead size, surface coatings, fluid velocity, and ionic strength on cell deposition onto process media [13]. A common approach to evaluate biomass deposition in laboratory packed-bed experiments employs the "clean-bed" filtration model (CBFM). In this case, mass transport phenomena are accounted by the "single-collector contact efficiency" $\left(\eta_{0}\right)$ while the physicochemical phenomena related to biomass attachment are reflected by the "attachment efficiency parameter" $(\alpha)$.

Streamline Phenyl materials (high-sub) were packed in commercial chromatographic columns ( $5 \mathrm{~mm}$ internal diameter, $50 \mathrm{~mm}$ length). The quality of the packing was evaluated by residence time distribution analysis employing $1 \%$ acetone as tracer [20]. Biomass deposition studies were done by injecting a $4 \mathrm{ml}$ biomass pulse (OD at $600 \mathrm{~nm} \approx 0.8 \mathrm{AU}$ ). Experiments were performed utilizing $20 \mathrm{mM}$ phosphate buffer $\mathrm{pH} 7$ or $50 \mathrm{mM}$ acetate buffer $\mathrm{pH}$ 4. Buffers contained various amounts of ammonium sulphate as added salt $(0.0,0.4,0.8,1.2,1.6,2.0 \mathrm{M})$. The operational flow rate was $76.4 \mathrm{~cm} \mathrm{~h}^{-1}$. Particle breakthrough curves were obtained by monitoring the effluent suspensions at $600 \mathrm{~nm}$. On the basis of such data, the biomass deposition parameter $(\alpha)$ was calculated [21]. Biomass deposition experiments were performed in triplicate and showed to be reproducible within $\pm 20 \%$.

\subsection{Energy-distance profile calculations}

The total interaction energy between a colloidal particle and a solid surface can be expressed in terms of the extended DLVO theory as:

$U_{\mathrm{mwc}}^{\mathrm{XDLVO}}=U_{\mathrm{mwc}}^{\mathrm{LW}}+U_{\mathrm{mwc}}^{\mathrm{EL}}+U_{\mathrm{mwc}}^{\mathrm{AB}}$ where $U^{\mathrm{XDLVO}}$ is the total interaction energy in aqueous media, $U^{\mathrm{LW}}$ is the LW interaction term, and $U^{\mathrm{EL}}$ is the EL interaction term. The subscript $m$ is utilized for the chromatographic matrix (adsorbent bead), $\mathrm{w}$ refers to the watery environment, and $\mathrm{c}$ to the colloidal (cell) particle. A third short-range $(\leq 5 \mathrm{~nm})$ Lewis $A B$ term is included to account for "hydrophobic attractive" and "hydrophilic repulsive" interactions [22].

Material surface energy parameters (tensions) can be calculated from contact angle measurements utilizing three diagnostic liquids, according to [23]. In turn, this data can be employed to evaluate the free energy of interaction between two defined surfaces $\left(\Delta G^{\mathrm{LW}}\right.$ and $\left.\Delta G^{\mathrm{AB}}\right) . \Delta G$ represents here the interaction energy per unit area between two (assumed) infinite planar surfaces bearing the properties of the adsorbent bead and the cell (interaction) or two cells (aggregation), respectively. Interaction between any of these two surfaces are evaluated at a closest distance of approximation $\left(h_{0} \approx 0.158 \mathrm{~nm}\right)$ [17]. When integrated into mathematical expressions accounting the geometric constraints existing between two interacting bodies, $\Delta G$ values can be utilized to calculate the corresponding energy-distance profile $(U v \mathrm{vs} . H)$. Details of this procedure were published [12,17]. $\Delta G^{\mathrm{LW}}$ are also related to the Hamaker constant, as follows:

$A=-12 \pi h_{0}^{2} \Delta G^{\mathrm{LW}}$

$U^{\mathrm{EL}}$ energy-distance profile can be calculated, assuming either plate-sphere or sphere-sphere geometry, upon experimental determination of particle zeta-potential values. Zeta-potential values are measured by electrophoretic mobility experiments [12]. Calculations were performed employing a commercial software package (GraphPad Prism, GraphPad Software Inc., San Diego, CA, USA).

\section{Results and discussions}

\subsection{Contact angle measurements and surface energy components}

The diagnostic liquids water, formamide, and $\alpha$-bromonaphtalene were employed to measure contact angles onto homogeneous lawns of the materials under study, i.e. intact yeast cells or crushed Phenyl-Sepharose beads. The sessile drop technique was employed. The utilization of the agar plate method assured that contact angle values were obtained for the mentioned materials in the hydrated state. Diagnostic liquids were chosen to have a higher surface tension than the sample materials so as to allow for stable drop formation and accurate contact angle determination. Both materials were carefully equilibrated with either $20 \mathrm{mM}$ phosphate buffer ( $\mathrm{pH} 7$ ) or $50 \mathrm{mM}$ acetate buffer $(\mathrm{pH} 4)$, which are buffers commonly encountered as mobile phases during hydrophobic interaction chromatography (HIC). Since conditions for binding proteins and macromolecules onto this particular chromatographic media are usually found at increased concentrations of ammonium sulphate, i.e. within the range $0.2-2.0 \mathrm{M}$, this salt was included during sample preparation. Therefore, contact angles with three different liquids were performed as a function of $\mathrm{pH}$ and salt concentration so as to evaluate material(s) properties within the normal HIC operational range.

Table 1 summarizes the contact angle values obtained after measurements performed onto homogeneous layers of intact yeast cells at $\mathrm{pH} 7$ and $\mathrm{pH}$ 4. The agar plate technique utilized allowed the measurement of contact angles under the assumption that only bound water is present in the sample materials. Irrespective of $\mathrm{pH}$ (phosphate buffer $\mathrm{pH} 7$ vs. acetate buffer $\mathrm{pH} 4$ ) and salt concentration (the ammonium sulphate concentration increased from $0 \mathrm{M}$ to $2 \mathrm{M}$ in the corresponding buffer solution), data gathered for contact 


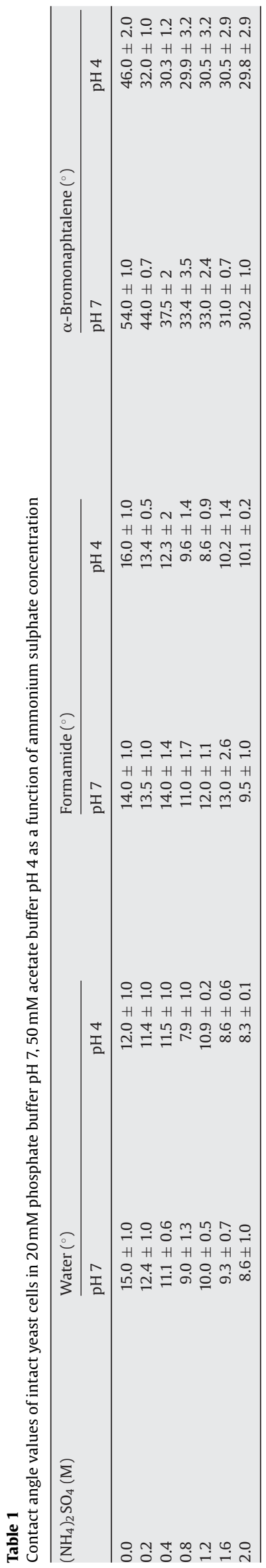

angles measured with both water and formamide overall showed low and nearly constant values. Average values for water were $\approx 10$ and for formamide $\approx 12$. This indicates the very hydrophilic nature of the samples. On the contrary, contact angles values gathered with $\alpha$-bromonaphtalene decreased from $\approx 54$ to $\approx 30$ and from $\approx 46$ to $\approx 30$ at $\mathrm{pH} 7$ and $\mathrm{pH} 4$, respectively, upon addition of salt. A more progressive decrease in the contact angle values was observed as a function of salt concentration - at $\mathrm{pH} 7$ than at $\mathrm{pH} 4$. In the later case, values for contact angles at varying salt concentrations tended to keep a constant level $(\approx 30)$ a condition which differentiates from the contact angle measured in plain buffer solution $(\approx 46)$. This indicates that a non-polar liquid can be employed to discriminate between biomass types or conditions in relation to surface hydrophobic character [24].

Table 2 shows contact angle values obtained by performing measurements onto layered fragments $(<10 \mu \mathrm{m})$ of the hydrophobic interaction media, Phenyl-Sepharose. This method was utilized since for soft gel particles other approaches, e.g. the capillary raise method are difficult to implement. Moreover, measurements onto layered materials showed good reproducibility, i.e. within $\pm 10 \%$ in triplicate measurements (Table 2). As described with biomass, a range of conditions was explored. At $\mathrm{pH} 7$ contact angle values were $\approx 6-7$ for water and $\approx 8-11$ for formamide, irrespective of salt concentration. On the other hand, a step change in the contact angle with $\alpha$-bromonaphtalene from $\approx 48$ (no salt) to $\approx 30$ (0.2-2.0 M ammonium sulphate) was noticed. At $\mathrm{pH} 4$ recorded contact angle values were $\approx 7-8$ with water and $\approx 9-10$ with formamide but observed values with $\alpha$-bromonaphtalene were progressively reduced from $\approx 36$ (no salt) to $\approx 22$ ( $2.0 \mathrm{M}$ ammonium sulphate). As a whole, these results stressed the known hydrophilic nature of the chromatographic beads, which are composed by an agarose backbone. Contact angles values observed with the apolar liquid also indicate an increased hydrophobic character in the presence of ammonium sulphate.

Global analysis of contact angle data suggests a decrease in the contact angle values, as a function of ammonium sulphate concentration, measured with $\alpha$-bromonaphtalene for cells and chromatographic beads. Contact angle values obtained for Phenyl-Sepharose with water and formamide were nearly constant irrespective of salt concentration. On the other hand, contact angles determined with the later two diagnostic liquids showed a trend to decrease when yeast cells were tested in the presence of salt.

Experimental contact angle determinations were utilized to calculate surface energy parameters for both biomass and chromatographic media according to the acid-base approach [17]. Calculated parameters reflect the contribution of the various energy components, i.e. Lifshitz-Van der Waals and acid-base (electronacceptor, electron-donor) to the total surface energy of a defined material. Table 3 depict the surface energy components $(\gamma)$ calculated for layered intact yeast cells as a function of $\mathrm{pH}$ ( 7 and 4) and ammonium sulphate concentration (0-2.0 M). As a general trend it was observed that $\gamma^{\mathrm{LW}}$ increased (e.g. from $28 \mathrm{~mJ} \mathrm{~m}^{-2}$ to $38 \mathrm{~mJ} \mathrm{~m}^{-2}$ at $\mathrm{pH} 7$ and from $32 \mathrm{~mJ} \mathrm{~m}^{-2}$ to $39 \mathrm{~mJ} \mathrm{~m}^{-2}$ at $\mathrm{pH} 4$ ) while $\gamma^{\mathrm{AB}}$ decreased (e.g. from $30 \mathrm{~mJ} \mathrm{~m}^{-2}$ to $18 \mathrm{~mJ} \mathrm{~m}^{-2}$ at $\mathrm{pH} 7$ and from $25 \mathrm{~mJ} \mathrm{~m}^{-2}$ to $18 \mathrm{~mJ} \mathrm{~m}^{-2}$ at $\mathrm{pH} 4$ ) as salt concentration was increased. Table 4 shows surface energy components for crushed chromatographic media as a function of $\mathrm{pH}$ and salt concentration, as before. At $\mathrm{pH} \mathrm{7,} \gamma^{\mathrm{LW}}$ increased from $31 \mathrm{~mJ} \mathrm{~m}^{-2}$ (no salt) to $39 \mathrm{~mJ} \mathrm{~m}^{-2}$ (0.4-2.0 M ammonium sulphate) while $\gamma^{\mathrm{AB}}$ decreased from $28 \mathrm{~mJ} \mathrm{~m}^{-2}$ (no salt) to $17 \mathrm{~mJ} \mathrm{~m}^{-2}$ (2.0 M ammonium sulphate). At $\mathrm{pH} 4$ a similar trend was noticed: $\gamma^{\mathrm{LW}}$ increased from $36 \mathrm{~mJ} \mathrm{~m}^{-2}$ (no salt) to $41 \mathrm{~mJ} \mathrm{~m}^{-2}\left(1.2-2.0 \mathrm{M}\right.$ ammonium sulphate) while $\gamma^{\mathrm{AB}}$ decreased from $21 \mathrm{~mJ} \mathrm{~m}^{-2}$ (no salt) to $15 \mathrm{~mJ} \mathrm{~m}^{-2}$ (2.0 M ammonium sulphate). As observed from Tables 3 and 4 , the parameter $\Delta G_{\text {iwi }}$ took always values $+23-27 \mathrm{~mJ} \mathrm{~m}^{-2}$ reflecting the hydrophilic nature 
Table 2

Contact angle values for Phenyl-Sepharose particles in $20 \mathrm{mM}$ phosphate buffer $\mathrm{pH} 7,50 \mathrm{mM}$ acetate buffer $\mathrm{pH} 4$ as a function of salt concentration

\begin{tabular}{|c|c|c|c|c|c|c|}
\hline \multirow[t]{2}{*}{$\left(\mathrm{NH}_{4}\right)_{2} \mathrm{SO}_{4}(\mathrm{M})$} & \multicolumn{2}{|l|}{ Water $\left(^{\circ}\right)$} & \multicolumn{2}{|c|}{ Formamide $\left(^{\circ}\right)$} & \multicolumn{2}{|c|}{$\alpha$-Bromonaphtalene $\left(^{\circ}\right)$} \\
\hline & $\mathrm{pH} 7$ & $\mathrm{pH} 4$ & $\mathrm{pH} 7$ & $\mathrm{pH} 4$ & $\mathrm{pH} 7$ & $\mathrm{pH} 4$ \\
\hline 0.0 & $6.0 \pm 1.0$ & $7.0 \pm 1.0$ & $10.0 \pm 1.0$ & $9.0 \pm 1.0$ & $48.0 \pm 4.8$ & $36.0 \pm 3.5$ \\
\hline 0.2 & $6.0 \pm 1.0$ & $7.3 \pm 0.5$ & $8.0 \pm 1.0$ & $10.0 \pm 1.0$ & $28.0 \pm 1.0$ & $28.5 \pm 0.5$ \\
\hline 0.4 & $6.0 \pm 1.0$ & $8.0 \pm 1.0$ & $8.0 \pm 1.0$ & $10.0 \pm 1.0$ & $23.7 \pm 2.5$ & $25.0 \pm 2.2$ \\
\hline 0.8 & $7.0 \pm 1.0$ & $7.4 \pm 0.5$ & $11.0 \pm 1.0$ & $9.0 \pm 1.0$ & $30.7 \pm 3.1$ & $23.0 \pm 1.0$ \\
\hline 1.2 & $7.0 \pm 1.0$ & $7.0 \pm 1.0$ & $10.0 \pm 1.0$ & $10.0 \pm 1.0$ & $24.0 \pm 2.5$ & $21.0 \pm 1.0$ \\
\hline 1.6 & $6.0 \pm 1.0$ & $7.7 \pm 0.5$ & $8.0 \pm 1.0$ & $9.0 \pm 1.0$ & $30.3 \pm 3.0$ & $22.3 \pm 1.0$ \\
\hline 2.0 & $7.0 \pm 1.0$ & $8.0 \pm 1.0$ & $11.0 \pm 1.0$ & $10.0 \pm 1.0$ & $32.0 \pm 3.5$ & $23.6 \pm 1.9$ \\
\hline
\end{tabular}

Table 3

Surface energy parameters of intact yeast cells in $20 \mathrm{mM}$ phosphate buffer $\mathrm{pH} 7,50 \mathrm{mM}$ acetate buffer $\mathrm{pH} 4$ as a function of ammonium sulphate concentration

\begin{tabular}{|c|c|c|c|c|c|c|c|c|c|c|c|c|}
\hline \multirow[t]{2}{*}{$\left(\mathrm{NH}_{4}\right)_{2} \mathrm{SO}_{4}(\mathrm{M})$} & \multicolumn{2}{|c|}{$\gamma^{\mathrm{LW}}\left(\mathrm{mJ} \mathrm{m}^{-2}\right)$} & \multicolumn{2}{|c|}{$\gamma^{+}\left(\mathrm{mJ} \mathrm{m}^{-2}\right)$} & \multicolumn{2}{|c|}{$\gamma^{-}\left(\mathrm{mJ} \mathrm{m}^{-2}\right)$} & \multicolumn{2}{|c|}{$\gamma^{\mathrm{AB}}\left(\mathrm{mJ} \mathrm{m}^{-2}\right)$} & \multicolumn{2}{|c|}{$\gamma^{\text {tot }}\left(\mathrm{mJ} \mathrm{m}^{-2}\right)$} & \multicolumn{2}{|c|}{$\Delta G_{\text {iwi }}\left(\mathrm{mJ} \mathrm{m}^{-2}\right)$} \\
\hline & $\mathrm{pH} 7$ & $\mathrm{pH} 4$ & $\mathrm{pH} 7$ & $\mathrm{pH} 4$ & $\mathrm{pH} 7$ & $\mathrm{pH} 4$ & pH 7 & $\mathrm{pH} 4$ & $\mathrm{pH} 7$ & $\mathrm{pH} 4$ & $\mathrm{pH} 7$ & $\mathrm{pH} 4$ \\
\hline 0.0 & 28.0 & 31.7 & 4.4 & 2.9 & 51.5 & 54.1 & 30.1 & 24.9 & 58.3 & 56.6 & +23.5 & +27.2 \\
\hline 0.2 & 33.0 & 37.8 & 2.7 & 1.5 & 53.2 & 54.3 & 24.1 & 18.0 & 56.9 & 55.8 & +26.0 & +26.7 \\
\hline 0.4 & 35.6 & 38.6 & 2.0 & 1.4 & 54.0 & 54.1 & 20.7 & 17.5 & 56.5 & 56.0 & +26.8 & +26.0 \\
\hline 0.8 & 37.4 & 38.6 & 1.6 & 1.5 & 54.7 & 54.0 & 18.6 & 17.9 & 56.0 & 56.5 & +27.2 & +25.7 \\
\hline 1.2 & 37.9 & 38.6 & 1.5 & 1.5 & 54.8 & 54.2 & 18.2 & 18.0 & 56.0 & 56.5 & +27.0 & +25.9 \\
\hline 1.6 & 38.0 & 38.6 & 1.5 & 1.5 & 54.8 & 54.3 & 18.0 & 18.0 & 56.0 & 56.6 & +27.1 & +26.0 \\
\hline 2.0 & 38.5 & 38.6 & 1.5 & 1.5 & 54.3 & 54.4 & 18.0 & 18.0 & 56.6 & 56.6 & +26.0 & +26.0 \\
\hline
\end{tabular}




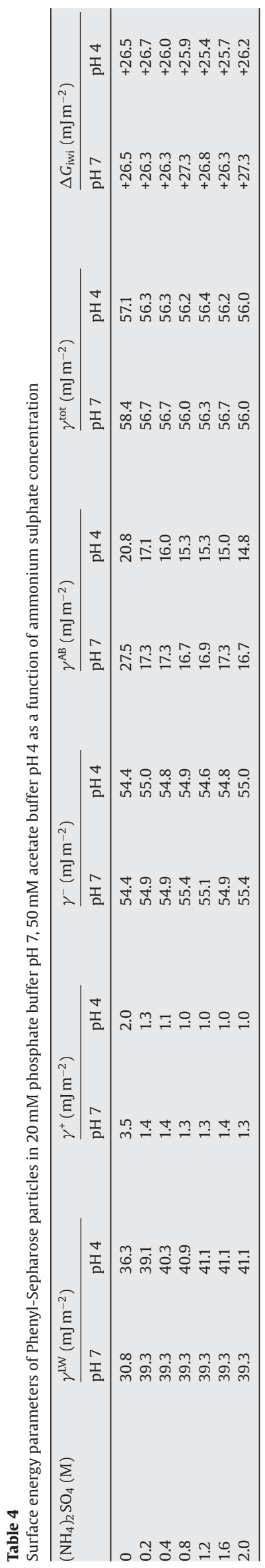

Table 5

Interfacial free energy of interaction between intact yeast cells and PhenylSepharose in $20 \mathrm{mM}$ phosphate buffer $\mathrm{pH} 7,50 \mathrm{mM}$ acetate buffer $\mathrm{pH} 4$ as a function of ammonium sulphate concentration

\begin{tabular}{|c|c|c|c|c|c|c|}
\hline \multirow[t]{2}{*}{$\left(\mathrm{NH}_{4}\right)_{2} \mathrm{SO}_{4}(\mathrm{M})$} & \multicolumn{2}{|c|}{$\Delta G^{\mathrm{LW}}\left(\mathrm{mJ} \mathrm{m}^{-2}\right)$} & \multicolumn{2}{|c|}{$\Delta G^{\mathrm{AB}}\left(\mathrm{mJ} \mathrm{m}^{-2}\right)$} & \multicolumn{2}{|c|}{$\Delta G^{\text {tot }}\left(\mathrm{mJ} \mathrm{m}^{-2}\right)$} \\
\hline & pH 7 & $\mathrm{pH} 4$ & $\mathrm{pH} 7$ & $\mathrm{pH} 4$ & pH 7 & pH 4 \\
\hline 0.0 & -1.1 & -2.6 & +27.2 & +32.4 & +26.1 & +29.8 \\
\hline 0.2 & -3.4 & -4.7 & +33.4 & +36.1 & +30.0 & +31.4 \\
\hline 0.4 & -4.1 & -5.2 & +35.0 & +36.5 & +30.9 & +31.3 \\
\hline 0.8 & -4.6 & -5.3 & +36.5 & +36.5 & +31.9 & +31.2 \\
\hline 1.2 & -4.8 & -5.4 & +36.5 & +36.5 & +31.7 & +31.0 \\
\hline 1.6 & -4.8 & -5.4 & +36.3 & +36.7 & +31.5 & +31.3 \\
\hline 2.0 & -4.9 & -5.4 & +36.5 & +37.0 & +31.6 & +31.6 \\
\hline
\end{tabular}

of the yeast cells and the chromatographic beads. For comparison, the $\Delta G_{\text {iwi }}$ of hydrophilic repulsion for Dextran T- 150 is $+41.2 \mathrm{~mJ} \mathrm{~m}^{-2}$ [22]. Concerning the materials acid-base character, particularly noticeable was a decrease of the values of the electron-acceptor parameter, i.e. up to $60 \%$ when comparing $\gamma^{-}$in the absence and presence of salt, respectively (Tables 3 and 4 ). $\gamma^{-}$values obtained via contact angle measurements more often pertain only to the global or averaged surface properties of the materials under study. Therefore, the agarose backbone onto which Phenyl ligands are immobilized is expected to have a major contribution to the overall material properties. On the other hand, differences in surface energy components might arise due to macromolecular changes within the cell envelop which can occur as a function of $\mathrm{pH}$ and salt concentration. The observed $\mathrm{AB}$ repulsion in aqueous media often explains the formation of stable suspensions of biological particles or stable dispersions of proteins and polysaccharides [25].

\subsection{Cell-to-support interaction}

\subsubsection{Interfacial free energy interaction and energy-distance profiles}

Interaction between biomass particles and chromatographic beads can be understood by calculating interfacial free energy $(U)$ vs. distance $(H)$ profiles. These calculations are based on the experimental determination of contact angles with three diagnostic liquids and the additional information gathered from zeta-potential determinations. Hydrophobic interaction chromatography is operated in a context characterized by an increased salt concentration (high ionic strength and conductivity) in the mobile phase, as well as, by uncharged beaded adsorbents. Therefore, it is expected that the information provided by contact angle determination will be more relevant to understand cell-to-support interactions than the information provided via $z$-potential determinations. Indeed, measurements of zeta potentials performed for Phenyl-Sepharose adsorbent particles under the experimental conditions reported in this work revealed very low values: $-2.0 \mathrm{mV}$ (base buffer) to $-0.1 \mathrm{mV}$ (high salt concentration). Zeta-potential values for yeast cells in diluted buffer solutions have been reported elsewhere but these values are expected to approach negligible values at high salt concentrations [5]. This situation is radically different from the case of the ion-exchangers where, due to the low conductivity of the mobile phases and the charged nature of the adsorbents, $z$-potential has been established as a parameter describing biomass deposition onto process supports [5].

Table 5 depicts the interfacial free energy of interaction between a biomass particles and a hydrophobic interaction bead, in aqueous media at $\mathrm{pH} 7$ or $\mathrm{pH} 4$, at closest distance of approximation ( $1.57 \AA$ ). The separation distance is determined by the balance between Born repulsion and Van der Waals attractive forces. At $\mathrm{pH} 7$ it can be observed that $\Delta G^{\mathrm{LW}}$ decreased from $-1.1 \mathrm{~mJ} \mathrm{~m}^{-2}$ (phosphate buffer) to $-4.9 \mathrm{~mJ} \mathrm{~m}^{-2}$ (salt containing buffer) indicating increas- 

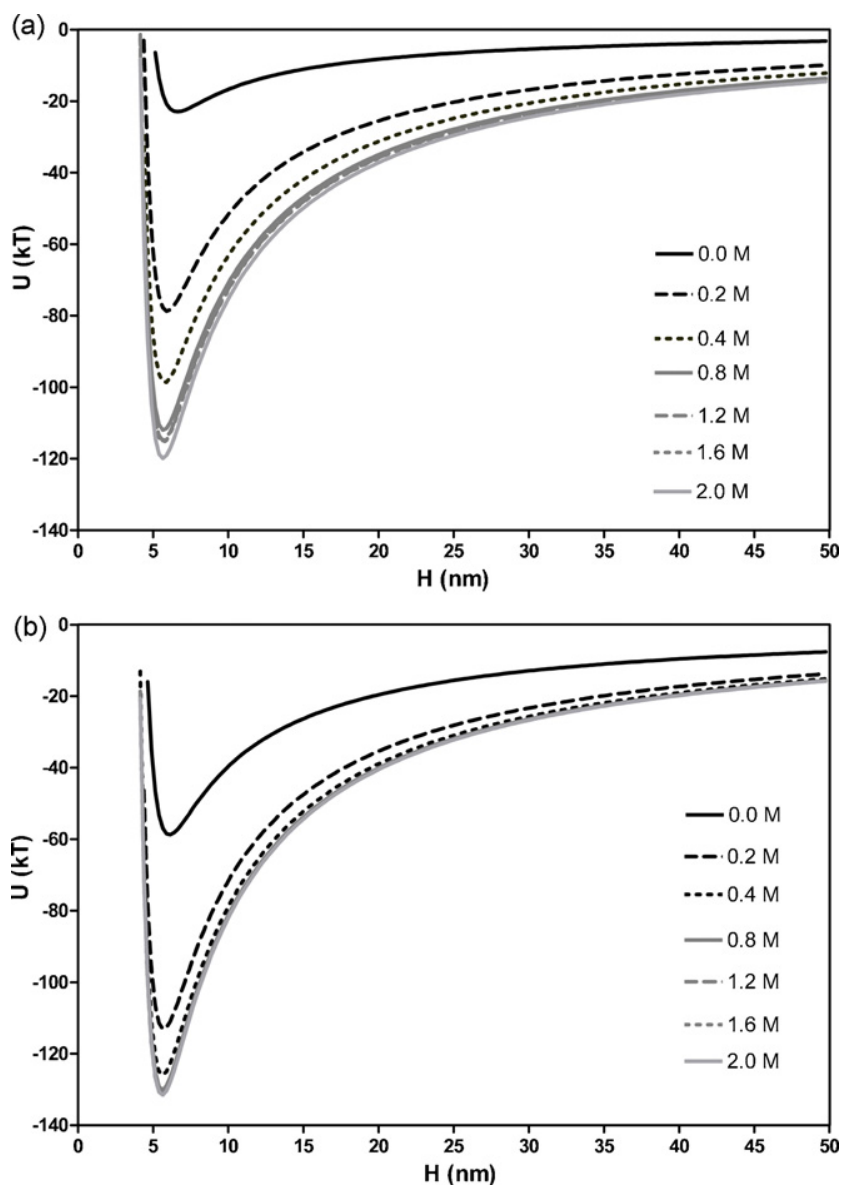

Fig. 1. Energy vs. distance profiles for interaction between intact yeast cells and hydrophobic interaction beads, at varying ammonium sulphate concentration. (a) $20 \mathrm{mM}$ phosphate buffer $\mathrm{pH}$ 7, (b) $50 \mathrm{mM}$ acetate buffer $\mathrm{pH} 4$.

ing LW attraction while $\Delta G^{\mathrm{AB}}$ increased from +27.2 (buffer) to +36.5 (salt) indicating enhanced repulsion by $\mathrm{AB}$ forces. At $\mathrm{pH} 4$ a similar trend was noticed.

The Hamaker constant $(A)$ for the interaction pair PhenylSepharose/yeast cells was calculated from $\Delta G^{\mathrm{LW}}$ according to Eq. (2). When calculated for dilute buffer solution, i.e. phosphate buffer $\mathrm{pH} 7$ and acetate buffer $\mathrm{pH} 4$, a value of $0.42 \mathrm{kT}$ was obtained. The calculated value for $A$ in buffers containing ammonium sulphate was $1.1 \mathrm{kT}$. Therefore, an influence of salt concentration but not of $\mathrm{pH}$ was observed on interaction Hamaker constant values; interaction refers to support-cell phenomena [24].

Utilizing the data provided before, i.e. $\Delta G^{\mathrm{LW}}, \Delta G^{\mathrm{AB}}$, and zetapotential values, interaction energy $(U)$ vs. distance $(H)$ profiles were calculated according to the XDLVO approach. Fig. 1( $\mathrm{a}$ and $\mathrm{b}$ ) shows the calculated secondary energy pockets occurring at $\approx 5 \mathrm{~nm}$ upon interaction of a yeast cell and the adsorbent surface. Calculations assumed sphere-to-plate geometry. This is justified since the adsorbent particles are bigger than the yeast particles by the factor of $\sim 40$. The depth of such energy pockets shifted from low to moderate values $\approx-20-50 \mathrm{kT}$ in dilute buffer solutions down to values $\approx-120 \mathrm{kT}$ at high salt concentrations. A more gradual modification of the involved interaction energies took place at $\mathrm{pH} 7$ than at $\mathrm{pH}$ 4. This is agreement with previous findings utilizing bacterial cells [7]. Stronger interaction energies between cells and fluidized beads in the presence of ammonium sulphate might explain observed biomass interference during direct HIC/EBA capturing of bioproducts from a crude feedstock [26].
Application of the extended DLVO approach is justified since due to the very polar nature of the buffer solutions where cell-adsorbent interactions take place, these interactions are known to be strongly influenced by polar Lewis acid-base (AB) or electron-acceptor/electron-donor forces. Contributions by electric double layer (EL) forces and particularly contributions by apolar Lifshitz-Van der Waals (LW) forces are also expected to occur. Important to the particular system considered here $\mathrm{EL}$ and $\mathrm{AB}$ forces decay exponentially with distance but as opposed to EL, the rate of decay of $A B$ forces with distance is independent on low to moderate variations in the ionic strength. On the other hand, LW interactions decay gradually and proportional to the separation distance between two bodies. As observed from Table 5, LW interactions were promoted upon salt addition. On the other hand, the pronounced asymmetry of the polar properties of hydrophilic materials like agarose-based chromatographic supports or biological particles promotes a strong $A B$ repulsion, i.e. hydrophilic repulsion. Taken as a whole, calculations performed in relation to interaction phenomena, i.e. cell-to-support interactions have shown hydrophilic $A B$ repulsion, increased LW attraction, and marginal contribution of EL forces under standard operational conditions.

The extended DLVO approach has served to explain the behavior of many other colloidal systems. Brandt and Childress have demonstrated that short-range interactions between synthetic membranes and bio-colloids can be better explained by taking into consideration the role of $\mathrm{AB}$ forces [27]. Van Oss and coworkers have studied the stability of a thixotropic suspension of $2 \mu \mathrm{m}$ hectorite particles and concluded that Lewis acid-base interactions play a key role in the coagulation dynamics of such system [28].

\subsubsection{Biomass deposition experiments}

Biomass deposition experiments were performed to evaluate yeast cells attachment to hydrophobic interaction supports. This allowed an independent experimental verification of the predictions made on the basis of energy vs. distance calculations (Fig. 1(a and $\mathrm{b})$ ).

Fig. 2(a and b) depicts the cell effluent profiles measured as a function of the chemical environment provided by the mobile phase. Ammonium sulphate concentration was systematically varied to observe its influence on cell attachment onto PhenylStreamline beads. Cell deposition was evaluated a pH 7 and 4 . Biomass deposition experiments showed a profound effect of salt concentration on cell effluent profiles, e.g. higher cell deposition with increased ammonium sulphate concentrations. From Fig. 2(a and $b$ ) it can also be noticed that and increased tendency exists for particles to be retained at $\mathrm{pH} 7$ (a) that at $\mathrm{pH} 4$ (b) when cell deposition was evaluated as a function of increasing ammonium sulphate concentration $(0-2 \mathrm{M})$.

This trend, i.e. increased deposition with neutral $\mathrm{pH}$ and increased salt concentration is reflected by $\alpha$, a lump parameter describing such phenomena (Table 6). For example utilizing either phosphate buffer $\mathrm{pH} 7$ or acetate buffer $\mathrm{pH} 4$, values for $\alpha$ were 0.065 and 0.031 , respectively. When ammonium sulphate was included in the mobile phase at a concentration of $2.0 \mathrm{M}, \alpha$ values were 0.443 at $\mathrm{pH} 7$ and 0.214 at $\mathrm{pH}$ 4. This "attachment efficiency" parameter depends on the experimental conditions set by the experimenter. In this case the method has been adapted to a chromatographic workstation that can operate in automatic mode. Therefore, the procedure can be implemented in any chromatographic laboratory and utilized to gather information without the need of more complicated experimental determinations like contact angle measurements or zeta-potential estimations. Qualitative and quantitative evaluation of cell deposition experiments can reveal several underlying phenomena like cell-to-support 

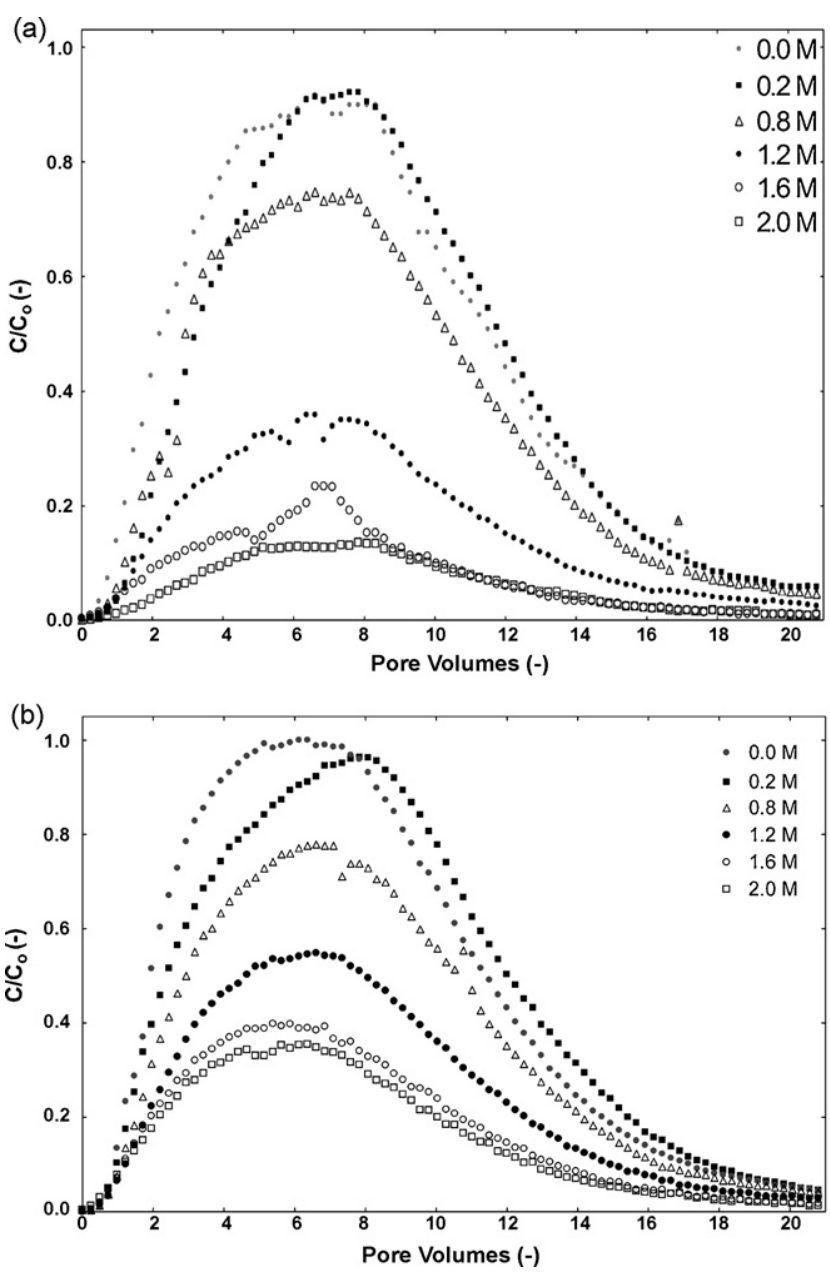

Fig. 2. Biomass deposition experiments as a function of salt concentration. (a) Phosphate buffer $\mathrm{pH} 7$, (b) acetate buffer $\mathrm{pH} 4$.

attachment (interaction), prevention of cell depositions by already deposited biomass particles (blocking), and cell-to-cell ripening (aggregation).

The biomass deposition experiment employs a bed of packed collectors which creates a more stable hydrodynamic situation in comparison with fluidized or expanded bed systems. Additionally, the biomass deposition experiment operates at a flow rate $(\sim 75 \mathrm{~cm} / \mathrm{h})$ that is lower than the flow rates expected during expanded bed operation $(\sim 300 \mathrm{~cm} / \mathrm{h})$. These experiments, however, were designed to confirm XDLVO calculations, e.g. to obtain information related to cell deposition onto the solid surface. Biomass deposition experiments were run under optimized

\section{Table 6}

Calculated lumped biomass-attachment parameter from biomass deposition experiments for Phenyl-Streamline ${ }^{\mathrm{TM}}$ particles vs. intact yeast cells in $20 \mathrm{mM}$ phosphate buffer $\mathrm{pH} 7,50 \mathrm{mM}$ acetate buffer $\mathrm{pH} 4$ as a function of ammonium sulphate concentration

\begin{tabular}{llllll}
\hline$\left(\mathrm{NH}_{4}\right)_{2} \mathrm{SO}_{4}(\mathrm{M})$ & \multicolumn{2}{c}{$\mathrm{C} / \mathrm{C}_{\mathrm{o}}(-)$} & \multicolumn{2}{c}{$\alpha(-)$} \\
\cline { 2 - 3 } \cline { 5 - 6 } & $\mathrm{pH} \mathrm{7}$ & $\mathrm{pH} \mathrm{4}$ & & $\mathrm{pH} \mathrm{7}$ & $\mathrm{pH} \mathrm{4}$ \\
\hline 0.0 & 0.677 & 0.829 & 0.065 & 0.031 \\
0.4 & 0.561 & 0.647 & 0.097 & 0.073 \\
0.8 & 0.493 & 0.551 & 0.118 & 0.100 \\
1.2 & 0.234 & 0.397 & 0.243 & 0.155 \\
1.6 & 0.129 & 0.321 & 0.343 & 0.190 \\
2.0 & 0.071 & 0.279 & 0.443 & 0.214 \\
\hline
\end{tabular}

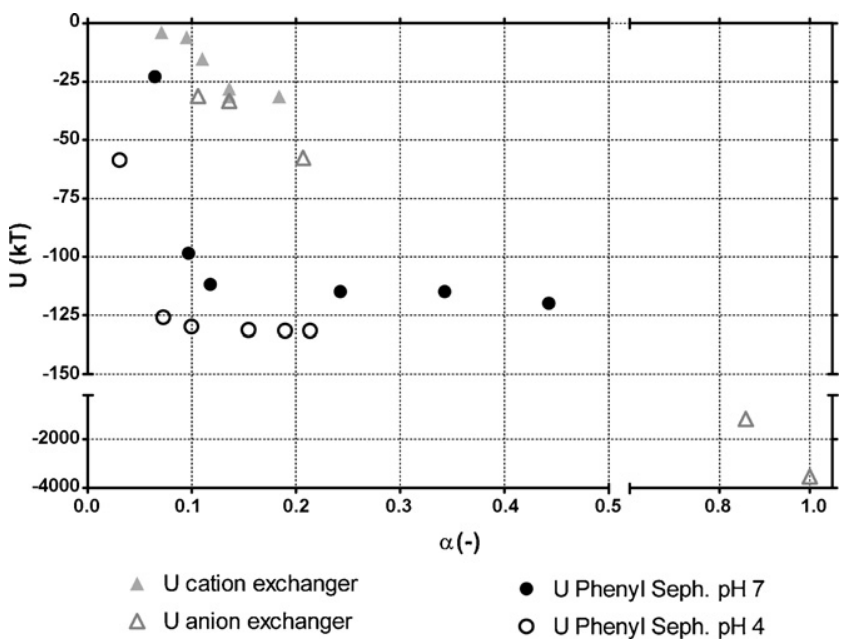

Fig. 3. Correlation between depth of free energy of interaction pocket and lumped attachment coefficient for several systems.

conditions with demonstrated sensibility to changes in XDLVO interactions. Studies performed as a function of superficial velocity were utilized to evaluate the interplay between cell-support attraction and cell detachment by hydrodynamic drag; no evidence of filtration effects was observed. This data will be published elsewhere.

Fig. 3 shows the correlation between the attachment efficiency parameter and the depth of the secondary free energy of interaction between a cell particle and a chromatographic bead. Points corresponding to hydrophobic interaction systems are presented within the frame of previous results gathered with ion-exchangers. It can be observed that conditions were no salt is present, and irrespective of $\mathrm{pH}$ and buffer chemical composition, are characterized by low deposition parameter values $(\leq 0.15)$ which correlate with limited energy pockets $(\leq|25-50| k \mathrm{~T})$. However, by adding ammonium sulphate to the flowing phase an increase in $\alpha$ values was noticed. The magnitude of this increment depended on $\mathrm{pH}$. For buffers at neutral $\mathrm{pH}$ the parameter $\alpha$ changed from $\approx 0.1(0.4 \mathrm{M}$ salt $)$ to $\approx 0.45$ (2.0 M salt). On the other hand, at pH 4 moderate changes in $\alpha$ were observed, e.g. from $\approx 0.07$ ( $0.4 \mathrm{M}$ salt) to $\approx 0.21$ ( $2.0 \mathrm{M}$ salt). Therefore, cell deposition in the presence of ammonium sulphate generally resulted in $\alpha \geq 0.15$. The later criterion has been set as threshold for problem-free operation during direct capture of bioproducts from a crude feedstock [13]. From a process performance point of view this could indicate hydrodynamic and sorption performance limitations from example, during expanded bed adsorption of bioproducts [26]. Sorption performance utilizing HIC/EBA systems has previously been reported [11]. Until now, however, it has been difficult to correlate such behavior with simple cell transmission indexes [3]. Biomass-impulse experiments, however, have shown to correlate with ion-exchanger sorption performance were electrostatic-driven cell-to-matrix interactions effects are predominant.

Analysis of the correlation between the depth of the interaction energy pockets and the attachment efficiency values for hydrophobic interaction materials in the presence of ammonium sulphate reveled differences with ion-exchange adsorbents. For HIC systems, a modification in $\alpha$ values correlated with discrete modifications in energy pocket values (Fig. 3). Moreover, extreme values of both attachment efficiency and energy valleys were not observed. These results, as a whole, might indicate that total deposition of biomass particles is mediated not only by cell-to-matrix interaction but also by cell-to-cell aggregation phenomena (ripening). Deposition 

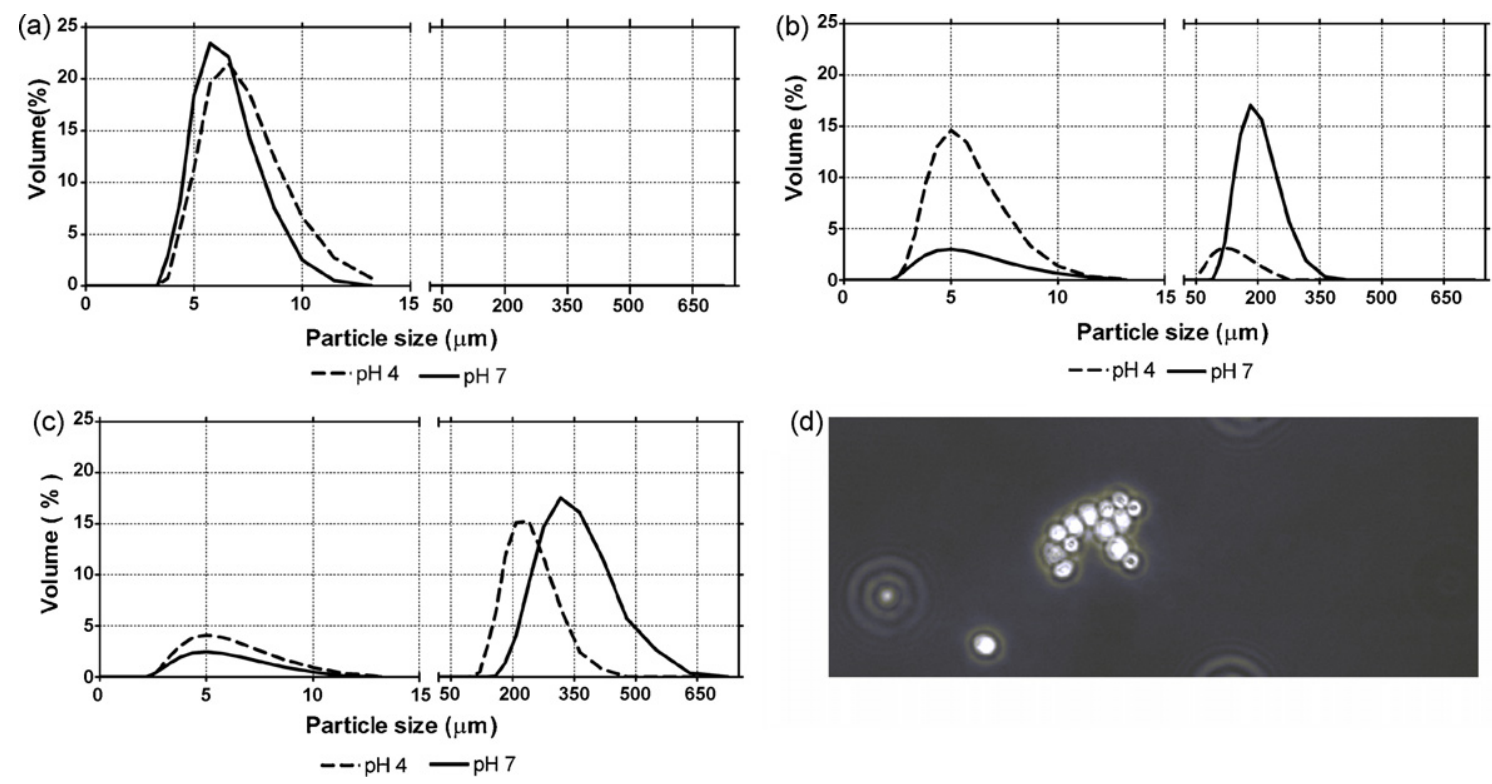

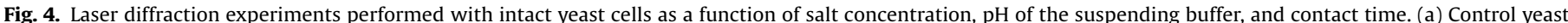

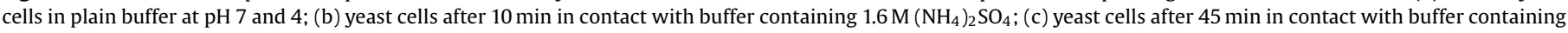
$1.6 \mathrm{M}\left(\mathrm{NH}_{4}\right)_{2} \mathrm{SO}_{4}$; (d) Visual aggregation of yeast cells suspended in $1.6 \mathrm{M}$ of salt.

experiments also seem to indicate that ripening is occurring in a larger extent at $\mathrm{pH} 7$ than at $\mathrm{pH}$ 4. Summarizing, for hydrophobic interaction systems modifications within a secondary interaction energy pocket occurred only from $-70 k \mathrm{~T}$ to $-120 k \mathrm{~T}$ but $\alpha$ values increased up to 0.45 when ammonium sulphate increased from $0 \mathrm{M}$ to $2 \mathrm{M}$ (Fig. 3).

Experiments performed to evaluate the influence of the age of the culture on cell attachment - as observed by biomass deposition experiments - showed increased $\alpha$ values when aged cells were employed. For example, in phosphate buffer $\mathrm{pH} 7$ containing $1.0 \mathrm{M}$ ammonium sulphate $\alpha$ increased from 0.20 to 0.36 when fresh cells were compared to an aged culture (data not shown). At $\mathrm{pH} 4$ a similar trend was observed with $\alpha$ increasing for 0.14-0.26 when considering late exponential phase vs. one day aged culture.

\subsection{Cell-to-cell aggregation}

Cell-to-cell aggregation might represent and important mechanism promoting overall cell attachment during biomass deposition experiments. Therefore, increased values for the lumped $\alpha$ parameter might indicate not only stronger cell-to-support interaction but also enhanced cell-to-cell aggregation. Consequently, results from biomass deposition experiments will reveal conditions prevailing during real process performance where both interaction and aggregation phenomena can coexist.

Contact angle and zeta-potential determinations, as reported in this work and elsewhere [5] have been utilized to calculate energy vs. distance profiles between two intact yeast cells. Sphereto-sphere geometry was assumed. These XDLVO calculations have indicated that:

(a) At closest distance of approximation $\Delta G^{\mathrm{LW}}$ took values between $-1.5 \mathrm{~mJ} \mathrm{~m}^{-2}$ (20 mM phosphate buffer $\left.\mathrm{pH} 7\right)$ and $-3.8 \mathrm{~mJ} \mathrm{~m}^{-2}$ (50 $\mathrm{mM}$ acetate buffer $\mathrm{pH} 4$ ) under the chemical environment provided by the buffering solutions employed. By adding increasing amounts of ammonium sulphate, i.e. up to $2 \mathrm{M} \Delta G^{\mathrm{LW}}$ values decreased to $-9.5 \mathrm{~mJ} \mathrm{~m}^{-2}$, irrespective of system $\mathrm{pH}$. Therefore, attraction between cell particles due to LW forces is similar at both $\mathrm{pH}$ values but increased with salt concentra- tion (Table 7). Hamaker constant values were $0.6 \mathrm{kT}$ (diluted buffer solution) and $2.0 \mathrm{kT}$ (added salt $\geq 0.4 \mathrm{M}$ ) for yeast-toyeast aggregation.

(b) Under similar conditions, $\Delta G^{\mathrm{AB}}$ showed more repulsion when calculating interfacial energy values at $\mathrm{pH} 4\left(\right.$ from $+31.0 \mathrm{~mJ} \mathrm{~m}^{-2}$ and up to $+35.6 \mathrm{~mJ} \mathrm{~m}^{-2}$ under buffer and added salt conditions, respectively) than when calculating interfacial energy values at $\mathrm{pH} 7$ (from $+25.0 \mathrm{~mJ} \mathrm{~m}^{-2}$ and up to $+36.0 \mathrm{~mJ} \mathrm{~m}^{-2}$ under buffer and added salt conditions, respectively). Therefore, the model biomass utilized in this work might have a tendency to be more stable, e.g. less aggregation under acidic $\mathrm{pH}$ conditions due to enhanced repulsion by $\mathrm{AB}$ forces (Table 7 ).

(c) Coulomb-type interactions are repulsive in nature, but of marginal importance when salt concentration is higher than $0.1 \mathrm{M}$ ammonium sulphate, e.g. EL are irrelevant under normal processing conditions.

(d) Calculations performed to evaluate energy vs. distance profiles for interaction between two cells in aqueous media have shown secondary energy pockets taking values within the range $-3 k \mathrm{~T}$ and $-11 k \mathrm{~T}$ under diluted buffer conditions and $\approx-30 k \mathrm{~T}$ in the presence of $2.0 \mathrm{M}$ ammonium sulphate (data not shown).

In order to elucidate cell aggregation behavior as a function of $\mathrm{pH}$ and salt concentration laser diffraction spectroscopic measurements were employed [19]. The implementation of an independent method to specifically evaluate cell-to-cell aggregation can help in

Table 7

Interfacial free energy of aggregation of intact yeast cells in $20 \mathrm{mM}$ phosphate buffer $\mathrm{pH} 7,50 \mathrm{mM}$ acetate buffer $\mathrm{pH} 4$ as a function of ammonium sulphate concentration

\begin{tabular}{|c|c|c|c|c|c|c|}
\hline \multirow[t]{2}{*}{$\left(\mathrm{NH}_{4}\right)_{2} \mathrm{SO}_{4}(\mathrm{M})$} & \multicolumn{2}{|c|}{$\Delta G^{\mathrm{LW}}\left(\mathrm{mJ} \mathrm{m} \mathrm{m}^{-2}\right)$} & \multicolumn{2}{|c|}{$\Delta G^{\mathrm{AB}}\left(\mathrm{mJ} \mathrm{m}^{-2}\right)$} & \multicolumn{2}{|c|}{$\Delta G^{\text {tot }}\left(\mathrm{mJ} \mathrm{m}^{-2}\right)$} \\
\hline & pH 7 & $\mathrm{pH} 4$ & pH 7 & $\mathrm{pH} 4$ & pH 7 & $\mathrm{pH} 4$ \\
\hline 0.0 & -1.5 & -3.8 & +25.0 & +31.0 & +23.5 & +27.2 \\
\hline 0.2 & -4.5 & -8.8 & +30.5 & +35.5 & +26.0 & +26.7 \\
\hline 0.4 & -6.7 & -9.5 & +33.5 & +35.6 & +26.8 & +26.0 \\
\hline 0.8 & -8.4 & -9.5 & +35.5 & +35.2 & +27.1 & +25.7 \\
\hline 1.2 & -8.8 & -9.5 & +35.9 & +35.4 & +27.0 & +25.9 \\
\hline 1.6 & -8.9 & -9.5 & +36.0 & +35.5 & +27.1 & +26.0 \\
\hline 2.0 & -9.5 & -9.5 & +35.6 & +35.6 & +26.0 & +26.0 \\
\hline
\end{tabular}


Table 8

Laser diffraction experimental data gathered for intact yeast cells as a function salt concentration, $\mathrm{pH}$ of the suspending buffer, and contact time

\begin{tabular}{llllcc}
\hline Time $(\mathrm{min})$ & $\mathrm{pH}^{\mathrm{a}}$ & $\left(\mathrm{NH}_{4}\right)_{2} \mathrm{SO}_{4}(\mathrm{M})$ & $d_{(0.1)}(\mu \mathrm{m})$ & $d_{(0.5)}(\mu \mathrm{m})$ & $d_{(0.9)}(\mu \mathrm{m})$ \\
\hline \multirow{2}{*}{$10 / 45$} & 7 & - & $4.3 \pm 1$ & $5.6 \pm 1$ & $7.6 \pm 1$ \\
& 4 & - & $4.6 \pm 1$ & $6.2 \pm 1$ & $8.7 \pm 0.5$ \\
10 & 7 & 1.6 & $4.7 \pm 0.5$ & $160.5 \pm 10$ & $231.5 \pm 20$ \\
& 4 & 1.6 & $3.5 \pm 0.5$ & $5.3 \pm 1$ & $117.5 \pm 5$ \\
45 & 7 & 1.6 & $5.2 \pm 1$ & $284.7 \pm 15$ & $409.0 \pm 25$ \\
& 4 & 1.6 & $4.3 \pm 0.5$ & $18.4 \pm 4$ & $275.3 \pm 15$ \\
\hline
\end{tabular}

${ }^{\mathrm{a}} \mathrm{pH}$ 7: $20 \mathrm{mM}$ phosphate buffer; $\mathrm{pH}$ 4: $50 \mathrm{mM}$ acetate buffer.

understanding (lumped) deposition coefficient values. For example, high $\alpha$ values in the absence of aggregation by light scattering can be attributed to strong cell-to-support attachment. On the contrary, high $\alpha$ values and strong aggregation can indicate a combined effect during biomass deposition. Fig. 4 depicts particle size for isolated yeast cells and formed aggregates, if any. Determinations were performed in $20 \mathrm{mM}$ phosphate buffer $\mathrm{pH} 7$ and in $50 \mathrm{mM}$ acetate buffer $\mathrm{pH} 4$, so as to reproduce the conditions found during biomass deposition experiments. Under these conditions, results indicated that cells were suspended without any association and existed as $\approx 8 \mu \mathrm{m}$ particles (Fig. $4(\mathrm{a})$ ). This is in perfect agreement with the known size of intact yeast cells. Similar experiments performed in the presence of $1.6 \mathrm{M}$ ammonium sulphate showed a faster cell-tocell aggregation at $\mathrm{pH} 7$ that at $\mathrm{pH} 4$ at short contact times (10 min) (Fig. 4(b)). Furthermore, longer contact times ( $45 \mathrm{~min}$ ) promoted the formation of larger aggregates at $\mathrm{pH} 7(\approx 400 \mu \mathrm{m})$ than at $\mathrm{pH} 4$ $(\approx 250 \mu \mathrm{m})$ (Fig. 4(c)). Laser diffraction experiments performed in the presence of salt were also able to show the shrinkage of individual yeast cell to $\approx 5 \mu \mathrm{m}$ (data not shown). Cell clumping in the presence of salt was confirmed by confocal microscopy (Fig. 4(d)). Table 8 summarizes quantitative information obtained after laser diffraction spectroscopic evaluation of the samples. Results are expressed as percentiles. The $d_{(0.1)}, d_{(0.5)}$, and $d_{(0.9)}$ values shown in Table 8 are indicating that $10 \%, 50 \%$ and $90 \%$ of the particles measured were less than or the equal to the size stated in each case. Sample replicates $(n=5)$ have indicated that the shear exerted by the instrument during the measurement process was not promoting aggregate disruption (Table 8 ).

\section{Conclusions}

A comprehensive approach to understand biomass deposition/adhesion onto process supports, with special emphasis on hydrophobic interaction surfaces have included interaction forces other than those purely electrostatic in nature and have utilized principles of colloid theory to explain biomass-adsorbent attachment at the local (particle) level. Within the classical DLVO theory approach, Lifshitz-Van der Walls (LW) and electrostatic interactions (EL) were considered. Other forces like acid-base (AB) interactions were included in the extended approach (XDLVO) so as to explain biomass interaction and aggregation phenomena.

Interaction between biomass particles and chromatographic beads was understood by calculating interfacial free energy $(U)$ vs. distance $(H)$ profiles. These calculations were based on the experimental determination of contact angles with three diagnostic liquids and the additional information gathered from zeta-potential determinations. Hydrophobic interaction chromatography is operated in a context characterized by an increased salt concentration (high ionic strength and conductivity) in the mobile phase, as well as, by uncharged beaded adsorbents. Therefore, it was expected that information provided by contact angle determination would be more relevant to understand cell-to-support interactions than the information provided via zeta-potential determinations.

Qualitative and quantitative evaluation of cell deposition experiments have revealed several underlying phenomena like cell-to-support sticking, prevention of cell depositions by already deposited biomass particles (blocking), and cell-to-cell aggregation (ripening). Analysis of the correlation between the depth of the interaction energy pockets and the deposition coefficient values for hydrophobic interaction materials in the presence of ammonium sulphate reveled differences with ion-exchange adsorbents. For HIC systems, modifications in $\alpha$ values were followed by discrete modifications in energy pocket depths. Moreover, extreme values of both deposition coefficients and energy valleys were not observed. These results, as a whole, might indicate that total deposition of biomass particles is mediated not only by cell-to-material interaction but also mainly by cell-to-cell aggregation phenomena (ripening).

Cell-to-cell aggregation has represented and important mechanism promoting overall cell adhesion during biomass deposition experiments. These results would indicate that similar phenomena would impact on real process performance. Cell aggregation behavior, as a function of $\mathrm{pH}$ and salt concentration, was confirmed by laser diffraction spectroscopic measurements. Besides direct attachment of cells to the beaded support, cell aggregation has contributed to elevated $\alpha$-parameter values, particularly at $\mathrm{pH}$ 7 , during biomass deposition experiments.

Summarizing, it was demonstrated that both cell-to-adsorbent (interaction) and cell-to-cell (aggregation) phenomena are responsible to biomass deposition onto hydrophobic interaction chromatographic materials. Interaction and aggregation was inferred from XDLVO calculations on the basis of contact angle and zetapotential measurements. Moreover, experimental confirmation was obtained by independent methods like biomass deposition experiments and laser diffraction spectrometry.

Further work is being performed in our laboratory in order to extent the observations reported in this paper to other adsorbent chemistries, biomass types of various characteristics, and broader operational windows. For example, cell debris shows stronger interactions with hydrophobic adsorbents than intact cells, because of the hydrophobic inner membrane. Additionally, the information provided by the XDLVO approach is being utilized to alleviate process limitations.

\section{Acknowledgements}

C.T. was financially supported by TUBITAK, the Turkish Scientific and Technical Research Council, Ankara Turkey. R.R.V.P. gratefully acknowledges a doctoral fellowship from Jacobs University. The authors would like thank Professor Udo Fritsching and Ms. Lydia Achelis, Department of Process Technology, University of Bremen, for helpful assistance during laser diffraction measurements.

\section{References}

[1] H.M. Fernandez-Lahore, R. Kleef, M. Kula, J. Thommes, The influence of complex biological feedstock on the fluidization and bed stability in expanded bed adsorption, Biotechnol. Bioeng. 64 (4) (1999) 484-496.

[2] D.Q. Lin, H.M. Fernandez-Lahore, M.R. Kula, J. Thommes, Minimising biomass/adsorbent interactions in expanded bed adsorption processes: a methodological design approach, Bioseparation 10 (1-3) (2001) 7-19.

[3] J. Feuser, J. Walter, M.R. Kula, J. Thommes, Cell/adsorbent interactions in expanded bed adsorption of proteins, Bioseparation 8 (1-5) (1999) 99-109.

[4] D.Q. Lin, P.J. Brixius, J.J. Hubbuch, J. Thommes, M.R. Kula, Biomass/adsorbent electrostatic interactions in expanded bed adsorption: a zeta potential study, Biotechnol. Bioeng. 83 (2) (2003) 149-157.

[5] D.Q. Lin, L.N. Zhong, S.J. Yao, Zeta potential as a diagnostic tool to evaluate the biomass electrostatic adhesion during ion-exchange expanded bed application, Biotechnol. Bioeng. 95 (1) (2006) 185-191. 
[6] H. Vergnault, R.M. Willemot, M. Mercier-Bonin, Non-electrostatic interactions between cultured Saccharomyces cerevisiae yeast cells and adsorbent beads in expanded bed adsorption: Influence of cell wall properties, Process Biochem. 42 (2) (2007) 244-251.

[7] T.A. Stenstrom, Bacterial hydrophobicity, an overall parameter for the measurement of adhesion potential to soil particles, Appl. Environ. Microbiol. 55 (1) (1989) 142-147.

[8] C.J. Smyth, P. Jonsson, E. Olsson, O. Soderlind, J. Rosengren, S. Hjerten, T. Wadstrom, Differences in hydrophobic surface characteristics of porcine enteropathogenic Escherichia-coli with or without K88 antigen as revealed by hydrophobic interaction chromatography, Infect. Immun. 22 (2) (1978) 462-472.

[9] S. Kang, H. Choi, Effect of surface hydrophobicity on the adhesion of S. cerevisiae onto modified surfaces by poly(styrene-ran-sulfonic acid) random copolymers, Colloids Surf. B: Biointerfaces 10 (46 (2)) (2005) 70-77.

[10] A. Mahn, J.A. Asenjo, Prediction of protein retention in hydrophobic interaction chromatography, Biotechnol. Adv. 23 (5) (2005) 359-368.

[11] M.P. Smith, M.A. Bulmer, R. Hjorth, N.J. Titchener-Hooker, Hydrophobic interaction ligand selection and scale-up of an expanded bed separation of an intracellular enzyme from Saccharomyces cerevisiae, J. Chromatogr. A 968 (1-2) (2002) 121-128.

[12] R.R. Vennapusa, S.M. Hunegnaw, R.B. Cabrera, M. Fernandez-Lahore, Assessing adsorbent-biomass interactions during expanded bed adsorption onto ion exchangers utilizing surface energetics, J. Chromatogr. A 1181 (1-2) (2008) 9-20.

[13] C. Tari, R.R. Vennapusa, R.B. Cabrera, M. Fernandez-Lahore, Colloid deposition experiments as a diagnostic tool for biomass attachment onto bioproduct adsorbent surfaces, J. Chem. Technol. Biotechnol. 83 (2008) 183-191.

[14] V. Ganeva, B. Galutzov, J. Teissie, Flow process for electroextraction of intracellular enzymes from the fission yeast, Schizosaccharomyces pombe, Biotechnol. Lett. 26 (11) (2004) 933-937.

[15] M. Henriques, K. Gasparetto, J. Azeredo, R. Oliveira, Experimental methodology to quantify Candida albicans cell surface hydrophobicity, Biotechnol. Lett. 24 (2002) 1111-1115.

[16] P.K. Sharma, K.H. Rao, Analysis of different approaches for evaluation of surface energy of microbial cells by contact angle goniometry, Adv. Colloid Interface Sci. 98 (3) (2002) 341-463.
[17] R. Bos, H.C. Van der Mei, H.J. Busscher, Physico-chemistry of initial microbial adhesive interactions-its mechanisms and methods for study, FEMS Microbiol. Rev. 23 (2) (1999) 179-230.

[18] R.H. Ottewill, J.N. Shaw, Electrophoretic studies on polystyrene lattices, J. Electroanal. Chem. 37 (1972) 133-142.

[19] S. Voloshin, M. Shleeva, A. Syroeshkin, A. Kaprelyants, The role of intercellular contacts in the initiation of growth and in the development of a transiently nonculturable state by cultures of Rhodococcus rhodochrous grown in poor media, Microbiology 74 (2005) 420-427.

[20] H. Bak, O.R.T. Thomas, Evaluation of commercial chromatographic adsorbents for the direct capture of polyclonal rabbit antibodies from clarified antiserum, J. Chromatogr. B 848 (1) (2007) 116-130.

[21] J.A. Redman, S.L. Walker, M. Elimelech, Bacterial adhesion and transport in porous media: role of the secondary energy minimum, Environ. Sci. Technol. 38 (6) (2004) 1777-1785.

[22] C.J. Van Oss, Long-range and short-range mechanisms of hydrophobic attraction and hydrophilic repulsion in specific and aspecific interactions, J. Mol. Recognit. 16 (4) (2003) 177-190.

[23] C.J. Van Oss, Interfacial Forces in Aqueous Media, Marcel Dekker, New York, 1994, p. viii, 440 pp.

[24] M.A. Butkus, D. Grasso, Impact of aqueous electrolytes on interfacial energy, J Colloid Interface Sci. 200 (1) (1998) 172-181.

[25] W. Wu, R.F. Giese, C.J. van Oss, Stability versus flocculation of particle suspensions in water-correlation with the extended DLVO approach for aqueous systems, compared with classical DLVO theory, Colloids Surf. B: Biointerfaces 14 (1999) 47-55

[26] H.M. Fernandez-Lahore, S. Geilenkirchen, K. Boldt, A. Nagel, M.R. Kula, J. Thommes, The influence of cell adsorbent interactions on protein adsorption in expanded beds, J. Chromatogr. A 873 (2) (2000) 195208.

[27] J.A. Brant, A.E. Childress, Assessing short-range membrane-colloid interactions using surface energetics, J. Membr. Sci. 203 (2002) 257273.

[28] D. Grasso, K. Subramaniam, M. Butkus, K. Strevett, J. Bergendahl, A review of non-DLVO interactions in environmental colloidal systems, Rev. Environ. Sci. Biotechnol. 1 (1) (2002) 17-38. 